\title{
BIOSINTESA SENYAWA FENOLIK ANTIOKSIDAN DARI LIMBAH KULIT PISANGKEPOK (Musa acuminata balbisiana C.) SECARA FERMENTASI SUBMERGED MENGGUNAKAN RHIZOPUS ORYZAE
}

\author{
Andre Siswaja, Adhitia Gunarto, Ery Susiany Retnoningtyas*) dan Aning Ayucitra \\ Laboratorium Teknologi Bioproses, Jurusan Teknik Kimia, Fakultas Teknik, Universitas Katolik Widya Mandala, \\ Jl. Kalijudan 37, Surabaya 60114, Indonesia, Telp. (031)3891264, Faks. (031)3891267 \\ ${ }^{*}$ Penulis korespondensi: ery.srt@gmail.com
}

\begin{abstract}
BIOSYNTHESIS OF PHENOLIC ANTIOXIDANT COMPOUNDS FROM KEPOK BANANA PEEL WASTE (Musa acuminata balbisiana $C$.) USING SUBMERGED FERMENTATION BY RHIZOPUS ORYZAE. Phenolic antioxidant compounds can be formed through a process of biosynthesis with the help of microorganism. Kepok banana peel waste contains nutrients that support the growth of Rhizopus oryzae producing phenolic antioxidant compounds through its secondary metabolism. The objective of this research was to study the effects of fermentation time, concentration of Kepok banana peel extracts, and concentration of $\left(\mathrm{NH}_{4}\right)_{2} \mathrm{SO}_{4}$ on Total Phenolic Content (TPC) of extracts substrate. Total Antioxidant Capacity (TAC) of extracts with the highest TPC value was also measured. TPC of extracts were analyzed by Folin-Ciocalteu method whilst TAC by 2,2-diphenyl-1picrylhydrazyl (DPPH) method. Rhizopus oryzae was grown on a substrate containing kepok banana peel extract (500 $\mathrm{g}$ of kepok banana peel/L of water and $1000 \mathrm{~g}$ of kepok banana peel/L of water), $\left(\mathrm{NH}_{4}\right)_{2} \mathrm{SO}_{4}$, and other nutrients. Results showed that extracts with the highest phenolic content were obtained after 72 hours fermentation on substrate containing $32.69 \mathrm{mg} / \mathrm{mL}$ of glucose (concentration of kepok banana peel $1000 \mathrm{~g} / \mathrm{L}$ of water) and $0.25 \% \mathrm{w} / \mathrm{v}\left(\mathrm{NH}_{4}\right)_{2} \mathrm{SO}_{4}$. The substrate had TPC of 582.07 mg Gallic Acid Equivalent (GAE)/L extract with TAC of $88.37 \%$.
\end{abstract}

Keywords: biosynthesis; kepok banana peel; phenolic antioxidant; Rhizopus oryzae

\begin{abstract}
Abstrak
Senyawa fenolik antioksidan dapat terbentuk melalui proses biosintesa dengan bantuan Rhizopus oryzae menggunakan substrat limbah kulit pisang kepok. Limbah kulit pisang kepok belum banyak dimanfaatkan dan memiliki nilai ekonomi rendah. Di sisi lain, kulit pisang kepok mengandung sejumlah nutrisi yang dapat mendukung pertumbuhan Rhizopus oryzae dalam memproduksi senyawa fenolik antioksidan. Penelitian ini bertujuan untuk mempelajari pengaruh waktu fermentasi, konsentrasi ekstrak kulit pisang kepok, dan konsentrasi $\left(\mathrm{NH}_{4}\right)_{2} \mathrm{SO}_{4}$ terhadap perolehan senyawa fenolik, serta mempelajari Total Antioxidant Capacity (TAC) untuk ekstrak dengan perolehan senyawa fenolik tertinggi. Dalam penelitian ini, Rhizopus oryzae ditumbuhkan pada substrat ekstrak kulit pisang kepok dengan variasi $500 \mathrm{~g}$ kulit pisang kepok/L air dan $1000 \mathrm{~g}$ kulit pisang kepok/L air serta penambahan $\left(\mathrm{NH}_{4}\right)_{2} \mathrm{SO}_{4}$ dengan variasi konsentrasi. Total Phenolic Content (TPC) diukur menggunakan metode Folin-Ciocalteu, sedangkan Total Antioxidant Capacity (TAC) dianalisis dengan metode DPPH (2,2-diphenyl-1-picrylhydrazyl). Hasil penelitian menunjukkan bahwa TPC tertinggi terkandung dalam konsentrasi ekstrak kulit pisang kepok $1000 \mathrm{~g} / \mathrm{L}$ air dengan penambahan 0,25\% b/v $\left(\mathrm{NH}_{4}\right)_{2} \mathrm{SO}_{4}$ ) yaitu 582,07 mg Gallic Acid Equivalent (GAE)/L ekstrak dengan TAC 88,37\% setelah fermentasi 72 jam.
\end{abstract}

Kata kunci: biosintesa; kulit pisang kepok; fenolik antioksidan; Rhizopus oryzae

How to Cite This Article: Siswaja, A., Gunarto, A., Retnoningtyas, E.S., dan Ayucitra, A., (2015), Biosintesa Senyawa Fenolik Antioksidan dari Limbah Kulit Pisangkepok (Musa acuminata balbisiana C.) secara Fermentasi Submerged Menggunakan Rhizopus oryzae, Reaktor, 15(4), 224-230, http://dx.doi.org/10.14710/reaktor.15.4.224230. 


\section{PENDAHULUAN}

Seiring berkembangnya teknologi dan zaman, sebagian besar masyarakat telah mengalami perubahan gaya hidup termasuk pola makan dan moda transportasi. Dengan perkembangan tersebut, semakin banyak pula masalah-masalah yang timbul bagi kesehatan, salah satunya adalah efek radikal bebas. Radikal bebas terbentuk di dalam tubuh secara alamiah sebagai hasil samping dari proses oksidasi dan pembakaran sel yang berlangsung pada waktu bernapas, metabolisme sel, dan pada waktu berolahraga. Dalam suatu kondisi, reaksi radikal bebas dengan molekul-molekul di dalam tubuh bisa menjadi berbahaya dan jika tidak dihentikan/dikendalikan akan menimbulkan stress oksidatif yang menyebabkan kerusakan sel dan berbagai penyakit (Halliwell, 1996). Senyawa ini juga dapat berasal dari paparan polusi asap kendaraan, asap rokok, makanan, logam berat, dan radiasi matahari. Oleh karena itu, tubuh memerlukan suatu substansi yang dapat menangkal radikal bebas tersebut, yaitu senyawa fenolik antioksidan. Salah satu kulit buah yang mengandung senyawa fenolik adalah buah pisang. Produksi buah pisang di Indonesia mencapai 4.874.439 ton/tahun atau $34 \%$ dari total produksi buah nasional (Ditjen Hortikultura, 2005). Kalimantan Selatan merupakan salah satu provinsi yang cukup banyak memproduksi buah pisang yaitu sebesar 67.362 ton/tahun, dimana $75-85 \%$ pisang yang diproduksi adalah jenis pisang kepok (Ditjen Hortikultura, 2005). Menurut Nagarajaiah dan Prakash (2011), kulit pisang merupakan sumber polifenol, karotenoid, dan senyawa bioaktif lainnya yang memiliki berbagai efek menguntungkan pada kesehatan. Jumlah total senyawa fenolik yang terdapat di dalam kulit pisang telah dilaporkan sebesar 0,9-3 gram/100 gram berat kering (Someya dkk., 2002; Nguyen dkk., 2003). Menurut Atun dkk. (2007), senyawa fenolik dalam kulit pisang yang bersifat antioksidan adalah golongan leukoantosianidin.

Kandungan senyawa fenolik dalam kulit pisang dapat ditingkatkan melalui proses fermentasi dengan bantuan mikroorganisme, salah satunya Rhizopus. Menurut Dey dan Kuhad (2014) kandungan TPC gandum yang terfermentasi oleh Rhizopus oryzae meningkat sebelas kali dari kandungan TPC gandum sebelum fermentasi. Hal serupa juga dikemukakan oleh Schmidt dkk. (2014), bahwa TPC pada kulit padi (rice bran) meningkat dua kali setelah difermentasi oleh Rhizopus oryzae. Jenis senyawa fenolik yang dihasilkan oleh Rhizopus sangat tergantung dari spesies dan jenis substrat tempat tumbuhnya (Dey dan Kuhad, 2014; Zielinski dan Kozlowska, 2000). Rhizopus menghasilkan enzim $\beta$-glucosidase. Enzim ini memegang peranan dalam proses pemutusan ikatan glikosida dengan fenolik (Correia dkk., 2004). Semua jenis senyawa fenolik yang ditemukan di dalam tanaman berikatan dengan karbohidrat seperti glikosida (Fresco dkk., 2006; Mar'atirrosyidah dan Estiasih, 2015). Ikatan fenolik dengan glikosida ini menurunkan kemampuannya sebagai antioksidan yang baik (Toma, dkk., 2001). Genus Rhizopus merupakan salah satu kelompok mikroorganisme yang paling menjanjikan dalam proses biosintesa senyawa fenolik. Selain itu, fungi dari genus ini tidak memproduksi zat beracun/toxic (Schmidt dkk., 2014). Proses biosintesa fenolik dengan genus Rhizopus dapat dilakukan dengan dua metode, yaitu fermentasi substrat padat dan fermentasi cair. Pada penelitian ini digunakan fermentasi cair atau submerged. Fermentasi cair lebih mudah dalam hal proses kontrol dan pemisahan enzim ekstraseluler, mycelia ataupun spora (Sandhya dkk., 2005; Costa dkk., 2013).

Penelitian ini bertujuan untuk mempelajari pengaruh konsentrasi ekstrak kulit pisang kepok, konsentrasi $\left(\mathrm{NH}_{4}\right)_{2} \mathrm{SO}_{4}$ dan waktu fermentasi terhadap perolehan senyawa fenolik, serta mempelajari TAC (Total Antioxidant Capacity) dengan metode DPPH (2,2-diphenyl-1-picrylhydrazyl) berdasarkan perolehan senyawa fenolik tertinggi. Konsentrasi ekstrak kulit pisang kepok dan $\left(\mathrm{NH}_{4}\right)_{2} \mathrm{SO}_{4}$ menjadi variabel yang dipelajari karena keduanya merupakan sumber makronutrisi karbon dan nitrogen (Shuler dan Kargi, 1992).

\section{METODE PENELITIAN Bahan}

Kulit pisang kepok diperoleh dari penjual gorengan di Jalan Gembong-Surabaya. Biakan Rhizopus oryzae BIO224AP diperoleh dari Jurusan Biologi Universitas Airlangga-Surabaya. Bahan-bahan kimia spesifikasi pro-analisis seperti $\left(\mathrm{NH}_{4}\right)_{2} \mathrm{SO}_{4}$ dan 3,5-dinitrosalicylic acid diperoleh dari Sigma-Aldrich, sedangkan $\mathrm{KH}_{2} \mathrm{PO}_{4}, \quad \mathrm{ZnSO}_{4} \cdot 7 \mathrm{H}_{2} \mathrm{O}, \quad \mathrm{MgSO}_{4} \cdot 7 \mathrm{H}_{2} \mathrm{O}$, Potato Dextrose Agar (PDA), reagen Folin-Ciocalteu, 2,2-diphenyl-1-picrylhydrazyl, dan gallic acid diperoleh dari Merck.

\section{Pembuatan Media}

Kulit pisang kepok dicuci dan dipotong-potong menjadi bagian yang lebih kecil, lalu diblender dengan air sebanyak $500 \mathrm{~g} \mathrm{kulit/L}$ air dan $1000 \mathrm{~g}$ kulit/L air. Setelah itu dilakukan pemisahan antara ampas (kulit pisang kepok) dengan ekstrak kulit pisang kepok. Ke dalam ekstrak kulit pisang kepok ditambahkan $\left(\mathrm{NH}_{4}\right)_{2} \mathrm{SO}_{4}$ sebanyak $0,0,25$, dan $0,5 \%$ $\mathrm{b} / \mathrm{v}$ (sesuai variasi penelitian), serta nutrisi pendukung yaitu $0,015 \mathrm{~g} \mathrm{KH}_{2} \mathrm{PO}_{4} ; 0,004 \mathrm{~g} \mathrm{ZnSO}_{4} \cdot 7 \mathrm{H}_{2} \mathrm{O}$; dan $0,025 \mathrm{~g} \mathrm{MgSO}_{4} \cdot 7 \mathrm{H}_{2} \mathrm{O}$ tiap $100 \mathrm{~mL}$ ekstrak kulit pisang kepok. Selanjutnya, dilakukan sterilisasi menggunakan autoklaf selama 15 menit pada suhu $121^{\circ} \mathrm{C}$ dan tekanan 15 psi.

\section{Pembuatan Starter dan Proses Fermentasi}

Biakan Rhizopus oryzae berumur 72 jam pada media PDA ditambahkan garam fisiologis dan dilakukan proses scrub. Selanjutnya sebanyak $5 \mathrm{~mL}$ suspensi spora Rhizopus oryzae dengan konsentrasi $1,7 \times 10^{7}$ spora/mL dimasukkan secara aseptik ke dalam $10 \mathrm{~mL}$ ekstrak kulit pisang kepok di dalam erlenmeyer 
$250 \mathrm{~mL}$, lalu diinkubasi pada suhu $30^{\circ} \mathrm{C}$ selama 72 jam. Kemudian ekstrak kulit pisang kepok sebanyak $90 \mathrm{~mL}$ ditambahkan sehingga volume substrat di masing-masing erlenmeyer (sebanyak 7 erlenmeyer) menjadi $100 \mathrm{~mL}$. Substrat lalu diinkubasi pada suhu $30^{\circ} \mathrm{C}$ selama 168 jam dan dilakukan pengamatan setiap 24 jam.

\section{Persiapan Analisa Sampel}

Sampel hasil fermentasi berupa senyawa fenolik yang larut dalam media fermentasi dipisahkan dari Rhizopus oryzae menggunakan corong Buchner dan kertas saring Whatman Nomor 40. Filtrat yang diperoleh dianalisis glukosa, nitrogen, TPC, dan TAC, sedangkan dried weight biomassa Rhizopus oryzae ditentukan dengan metode gravimetri.

\section{Analisa glukosa}

Sisa glukosa yang terkandung dalam hasil fermentasi ditentukan dengan metode dinitrosalicylic acid (Lee, 1992). Satu $\mathrm{mL}$ sampel yang telah ditambahkan $3 \mathrm{~mL}$ reagen dinitrosalicylic acid dipanaskan dalam air mendidih selama 5 menit. Setelah dingin, diukur absorbansi dengan menggunakan spektrofotometer UV-VIS (Genesys ${ }^{\mathrm{TM}}$ 10UV) pada panjang gelombang $511 \mathrm{~nm}$.

\section{Analisa nitrogen}

Kandungan sisa nitrogen dalam hasil fermentasi ditentukan dengan metode Kjeldahl (Sudarmadji dkk., 2007). Satu mL sampel yang telah ditambahkan 2,5 gram tablet Kjeldahl dan $10 \mathrm{~mL}$ larutan $\mathrm{H}_{2} \mathrm{SO}_{4}$ pekat, dipanaskan di dalam labu Kjeldahl hingga cairan menjadi jernih. Setelah sampel dingin, ditambahkan $100 \mathrm{~mL}$ aquades dingin dan 50 $\mathrm{mL} \mathrm{NaOH} 50 \%$ dingin secara perlahan. Selanjutnya larutan didistilasi dan $75 \mathrm{~mL}$ distilat yang dihasilkan ditambahkan dengan $50 \mathrm{~mL}$ larutan standar $\mathrm{HCl} 0,1 \mathrm{~N}$ yang telah diberi indikator metil merah. Distilat dititrasi dengan larutan standar $\mathrm{NaOH} 0,1 \mathrm{~N}$ hingga berwarna kuning.

\section{Analisa TPC}

Kandungan TPC pada hasil fermentasi ditentukan menggunakan metode Folin-Ciocalteu (Marinova dkk., 2005) dengan modifikasi. Satu mL sampel dimasukkan dalam labu ukur $25 \mathrm{~mL}$, ditambahkan $9 \mathrm{~mL}$ aquabides dan $1 \mathrm{~mL}$ reagen FolinCiocalteu, selanjutnya dikocok sehingga homogen. Setelah didiamkan selama 5 menit, ditambahkan 10 mL larutan $\mathrm{Na}_{2} \mathrm{CO}_{3} \quad 7 \%$ dan diencerkan dengan aquabides sehingga volumenya $25 \mathrm{~mL}$ selanjutnya dikocok hingga homogen. Setelah diinkubasikan selama 90 menit pada temperatur kamar, sampel diukur absorbansinya dengan menggunakan spektrofotometer UV-VIS (Genesys ${ }^{\mathrm{TM}}$ 10UV) pada panjang gelombang $741 \mathrm{~nm}$. TPC dinyatakan sebagai ekuivalen asam galat (Gallic Acid Equivalent/GAE) per liter ekstrak.

\section{Analisa TAC}

Aktivitas antioksidan pada hasil fermentasi ditentukan menggunakan metode DPPH (Andayani dkk., 2008) dengan modifikasi. Filtrat yang sudah diuapkan pelarutnya, diambil 0,01 gram kemudian dilarutkan dalam sedikit etanol. Selanjutnya dipindahkan di labu ukur $10 \mathrm{~mL}$ dan diencerkan dengan etanol sehingga volumenya $10 \mathrm{~mL}$ dan dikocok hingga homogen. Sebanyak $0,2 \mathrm{~mL}$ larutan tersebut (sampel) ditambahkan dengan larutan DPPH $0,02 \mathrm{mg} / \mathrm{mL}$ sebanyak $3,8 \mathrm{~mL}$, kemudian dihomogenkan. Setelah didiamkan selama 30 menit di tempat gelap, diukur absorbansinya dengan menggunakan spektrofotometer UV-VIS (Genesys ${ }^{\mathrm{TM}}$ 10UV) pada panjang gelombang $520 \mathrm{~nm}$. TAC dinyatakan sebagai scavenging activity.

Scavenging activity $=($ absorbansi kontrol - absorbansi sampel)/absorbansi kontrol x 100\%

Keterangan :

Absorbansi kontrol $=$ Serapan radikal DPPH 0,02 $\mathrm{mg} / \mathrm{mL}$ pada panjang gelombang $520 \mathrm{~nm}$

Absorbansi sampel $=$ Serapan sampel dalam radikal DPPH 0,02 mg/mL pada panjang gelombang $520 \mathrm{~nm}$.

\section{Dried weight biomassa}

Dried weight biomassa Rhizopus oryzae ditentukan dengan metode gravimetri. Biomassa yang sudah terpisah dari media fermentasi dikeringkan di dalam oven Memmert pada suhu $60^{\circ} \mathrm{C}$ dan ditimbang. Proses pengeringan dan penimbangan dilakukan berulang sehingga diperoleh massa yang konstan.

\section{HASIL DAN PEMBAHASAN \\ Pengaruh Konsentrasi Ekstrak Kulit Pisang Kepok Terhadap TPC dan TAC}

Konsentrasi ekstrak kulit pisang kepok $500 \mathrm{~g} / \mathrm{L}$ air mengandung glukosa mula-mula $15,17 \mathrm{mg} / \mathrm{mL}$, sedangkan untuk konsentrasi ekstrak kulit pisang kepok $1000 \mathrm{~g} / \mathrm{L}$ air mengandung glukosa mula-mula 32,69 mg/mL. Glukosa mula-mula tersebut berasal dari kulit pisang kepok. TPC pada konsentrasi ekstrak $500 \mathrm{~g}$ kulit pisang kepok/L air dan $1000 \mathrm{~g}$ kulit pisang kepok/L air memiliki kecenderungan meningkat jika dibandingkan sebelum fermentasi. Peningkatan TPC pada kedua konsentrasi terjadi pada rentang waktu yang sama yaitu antara 0-72 jam dan setelah 72 jam cenderung konstan (Gambar 1). Hasil ini sedikit berbeda dengan fermentasi yang dilakukan oleh Schmidt dkk. (2014) dengan menggunakan rice bran sebagai substrat dan Rhizopus oryzae sebagai mikroba dimana TPC tertinggi diperoleh setelah waktu fermentasi 120 jam. Perbedaan metode fermentasi serta substrat yang digunakan mempengaruhi waktu perolehan TPC dalam proses fermentasi. Terlebih lagi jika jenis mikroba yang digunakan berbeda akan semakin memberikan variasi hasil. 


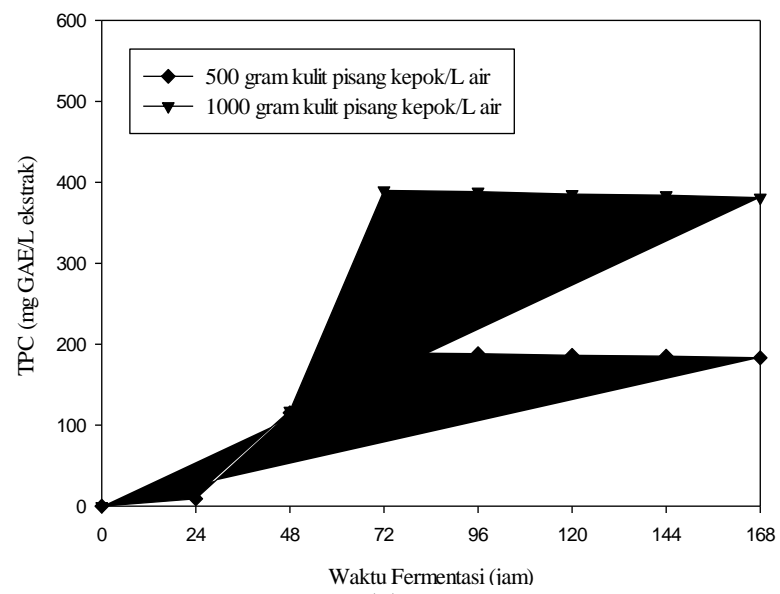

(a)

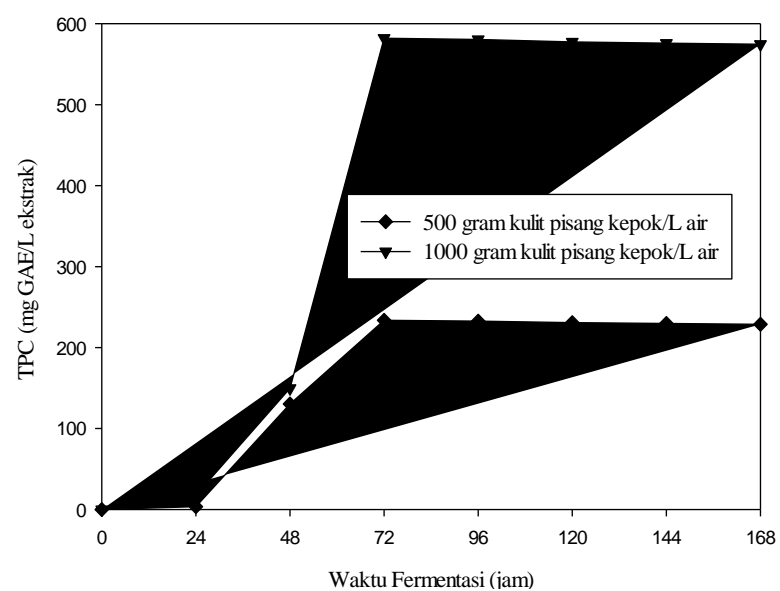

(b)

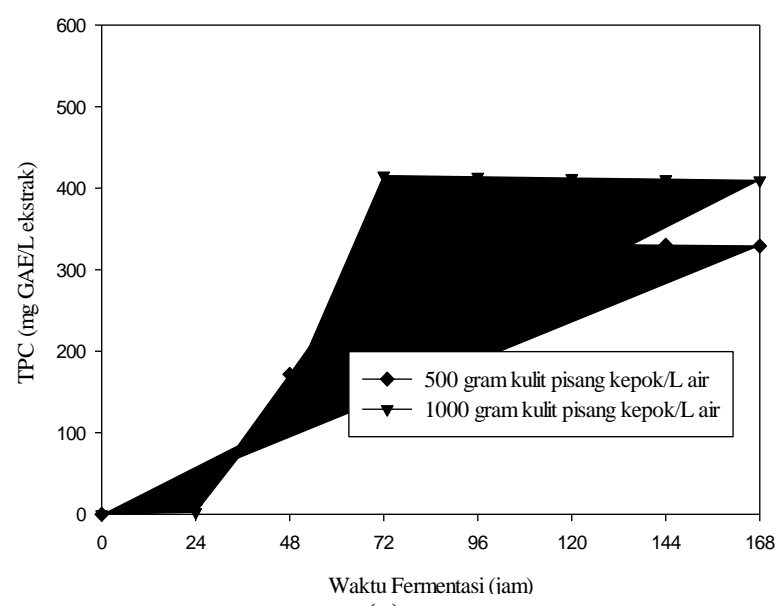

(c)

Gambar 1. TPC Rhizopus oryzae pada konsentrasi ekstrak kulit pisang kepok $500 \mathrm{~g} / \mathrm{L}$ air dan $1000 \mathrm{~g} / \mathrm{L}$ air untuk penambahan $\left(\mathrm{NH}_{4}\right)_{2} \mathrm{SO}_{4}$ : (a) $0 \% \mathrm{~b} / \mathrm{v}$, (b) $0,25 \% \mathrm{~b} / \mathrm{v}$, dan (c) $0,5 \% \mathrm{~b} / \mathrm{v}$

Pada Gambar 1, TPC pada konsentrasi ekstrak $1000 \mathrm{~g}$ kulit pisang kepok/L air yang mengandung $32,69 \mathrm{mg} / \mathrm{mL}$ glukosa mula-mula, lebih tinggi daripada TPC pada konsentrasi ekstrak $500 \mathrm{~g}$ kulit pisang kepok/L air yang mengandung $15,17 \mathrm{mg} / \mathrm{mL}$ glukosa mula-mula. Hal ini disebabkan karena enzim $\beta$-glukosidase yang diproduksi oleh Rhizopus oryzae lebih tinggi sehingga banyak fenolik bebas yang terlarut di ekstrak $1000 \mathrm{~g}$ kulit pisang kepok/L air. Enzim $\beta$-glukosidase ini berperan dalam pemutusan ikatan fenolik glikosida (Correia dkk., 2004).

Peristiwa ini juga dapat dikaitkan dengan konsumsi glukosa dan nitrogen (Gambar 2 dan Gambar 3) dimana pada rentang waktu 0-72 jam untuk kedua konsentrasi ekstrak kulit pisang tersebut menunjukkan penurunan yang drastis. Penurunan ini menunjukkan konsumsi nutrisi yang tinggi karena Rhizopus oryzae sedang berada di dalam fase eksponensial. Hal ini didukung oleh hasil analisis dried weight biomassa Rhizopus oryzae untuk kedua konsentrasi ekstrak tersebut (Gambar 4) yang meningkat pada rentang waktu 0-72 jam. Tetapi, dried weight biomassa pada konsentrasi ekstrak $1000 \mathrm{~g}$ kulit pisang kepok/L air lebih tinggi daripada dried weight biomassa pada konsentrasi ekstrak 500 g kulit pisang kepok/L air. Hal ini menunjukkan pertumbuhan Rhizopus oryzae lebih baik pada konsentrasi ekstrak $1000 \mathrm{~g}$ kulit pisang kepok/L air.

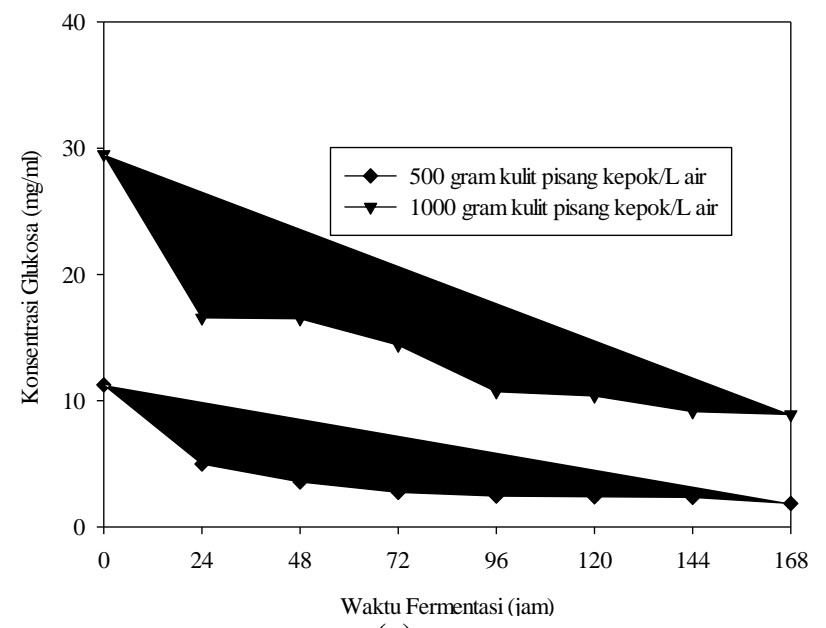

(a)

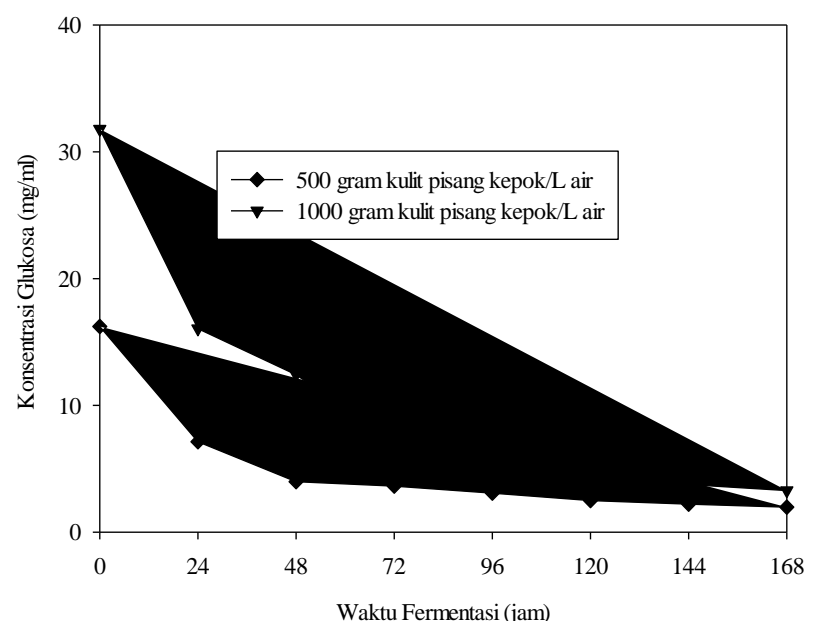

(b) 


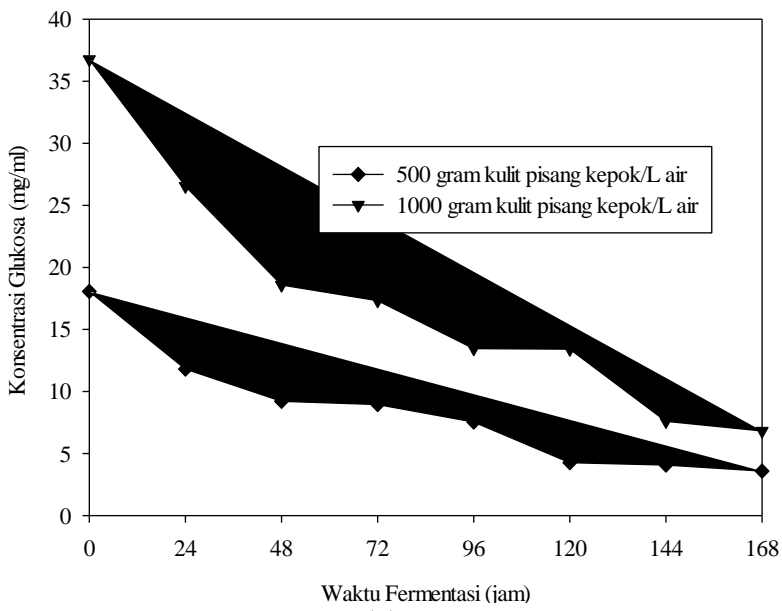

(c)

Gambar 2. Kandungan glukosa selama proses fermentasi pada konsentrasi ekstrak kulit pisang kepok $500 \mathrm{~g} / \mathrm{L}$ air dan $1000 \mathrm{~g} / \mathrm{L}$ air untuk penambahan $\left(\mathrm{NH}_{4}\right)_{2} \mathrm{SO}_{4}$ : (a) $0 \% \mathrm{~b} / \mathrm{v}$, (b) $0,25 \% \mathrm{~b} / \mathrm{v}$, dan (c) $0,5 \%$ $\mathrm{b} / \mathrm{v}$

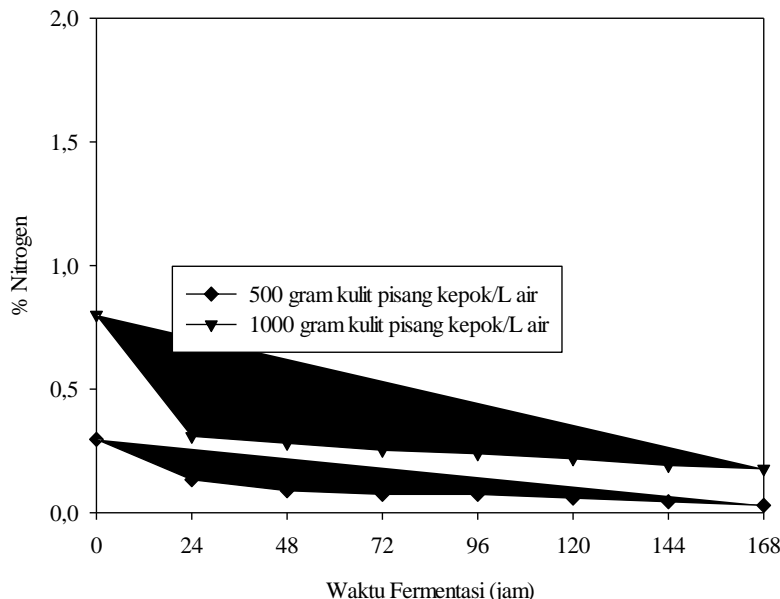

(a)

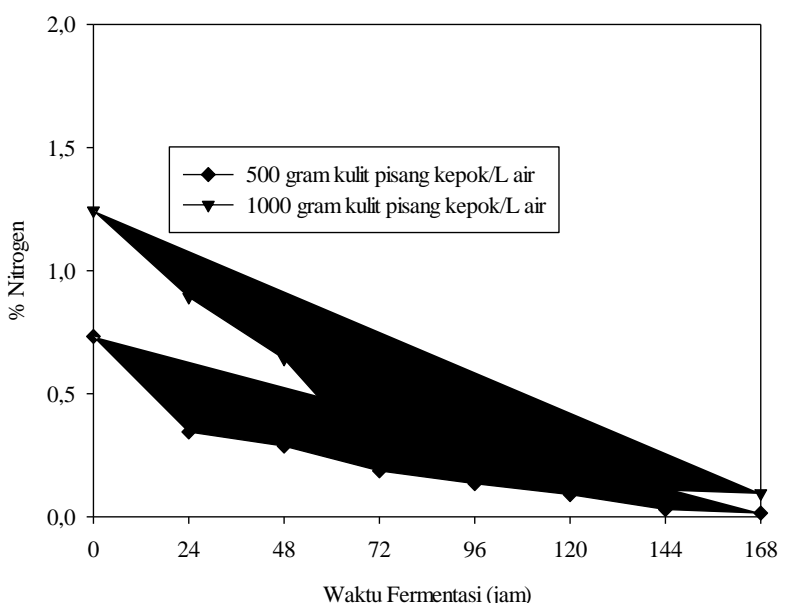

(b)

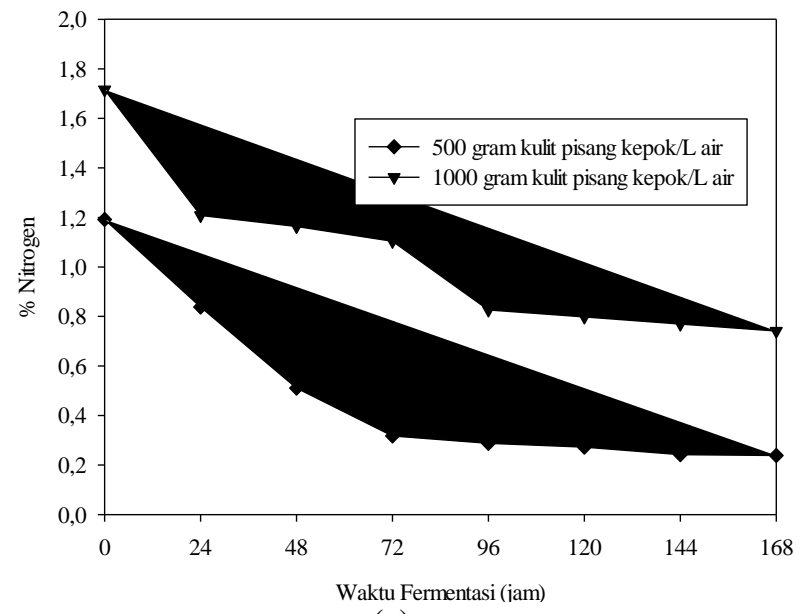

(c)

Gambar 3. Kadar nitrogen selama proses fermentasi pada konsentrasi ekstrak kulit pisang kepok $500 \mathrm{~g} / \mathrm{L}$ air dan $1000 \mathrm{~g} / \mathrm{L}$ air untuk penambahan $\left(\mathrm{NH}_{4}\right)_{2} \mathrm{SO}_{4}$ :

(a) $0 \% \mathrm{~b} / \mathrm{v}$, (b) $0,25 \% \mathrm{~b} / \mathrm{v}$, dan (c) $0,5 \% \mathrm{~b} / \mathrm{v}$

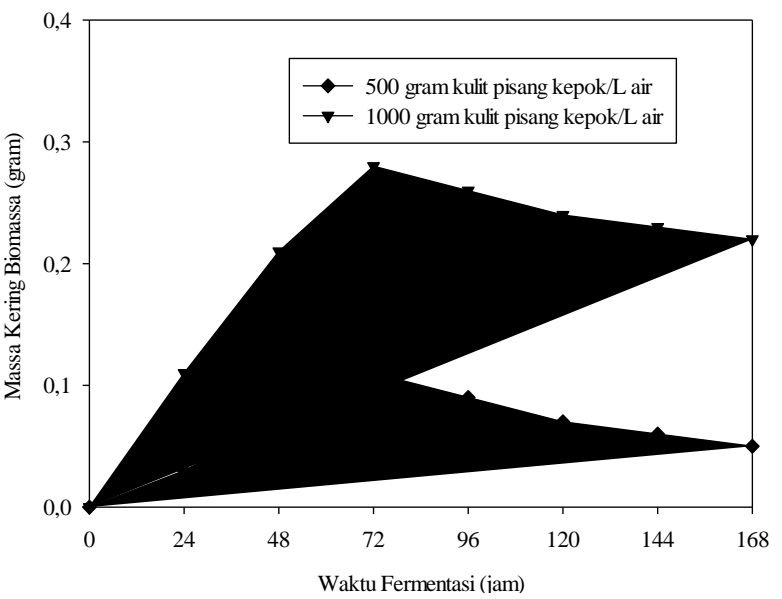

(a)

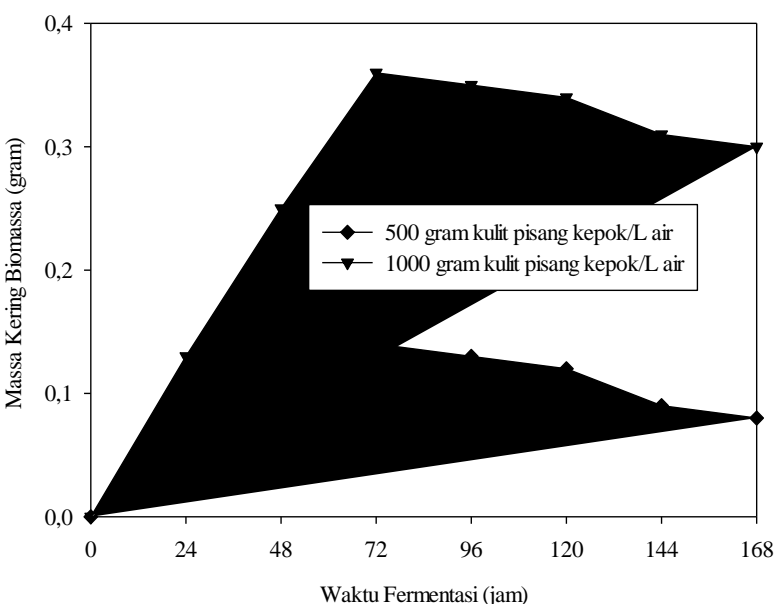

(b) 


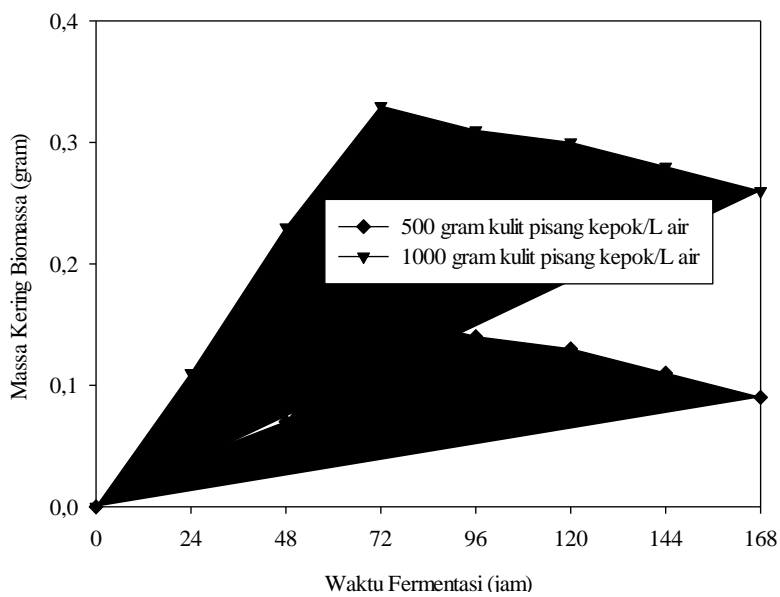

(c)

Gambar 4. Dried weight dari biomassa pada konsentrasi ekstrak kulit pisang kepok $500 \mathrm{~g} / \mathrm{L}$ air dan $1000 \mathrm{~g} / \mathrm{L}$ air untuk penambahan $\left(\mathrm{NH}_{4}\right)_{2} \mathrm{SO}_{4}$ : (a) $0 \%$ $\mathrm{b} / \mathrm{v}$, (b) $0,25 \% \mathrm{~b} / \mathrm{v}$, dan (c) $0,5 \% \mathrm{~b} / \mathrm{v}$

Perolehan TAC tertinggi dalam penelitian ini adalah $88,37 \%$. TAC ini lebih tinggi dibandingkan dengan penelitian yang dilakukan oleh Tjitradjaja dkk. (2011) dengan aktivitas tertinggi dari antioksidan sebesar 82,32\%. Tjitradjaja dkk. (2011) menggunakan metode fermentasi substrat cair ekstrak kulit pisang kepok dengan mikroba Aspergillus niger. Perbedaan jenis mikroba yang digunakan dalam proses fermentasi ikut mempengaruhi perolehan TAC.

\section{Pengaruh Konsentrasi $\left(\mathrm{NH}_{4}\right)_{2} \mathrm{SO}_{4}$ terhadap TPC dan TAC}

Dilihat dari Gambar 1, TPC mengalami peningkatan seiring dengan bertambahnya kadar nitrogen akibat penambahan konsentrasi $\left(\mathrm{NH}_{4}\right)_{2} \mathrm{SO}_{4}$ dari $0,0,25$ hingga $0,5 \% \mathrm{~b} / \mathrm{v}$ pada konsentrasi ekstrak kulit pisang kepok $500 \mathrm{~g} / \mathrm{L}$ air pada waktu 72 jam fermentasi berturut-turut adalah 189,17; 233,66 dan 333,12 mg GAE/L ekstrak. Namun hal ini berbeda untuk TPC pada konsentrasi ekstrak kulit pisang kepok $1000 \mathrm{~g} / \mathrm{L}$ air dimana hasil TPC tertinggi diperoleh pada penambahan konsentrasi $\left(\mathrm{NH}_{4}\right)_{2} \mathrm{SO}_{4}$ sebesar 0,25\% b/v yaitu 582,07 mg GAE/L ekstrak. Keadaan ini menunjukkan Rhizopus oryzae dapat tumbuh optimal dalam ekstrak kulit pisang kepok $1000 \mathrm{~g} / \mathrm{L}$ air dan $1,24 \%$ nitrogen yang terkandung dalam penambahan $\left(\mathrm{NH}_{4}\right)_{2} \mathrm{SO}_{4}$ sebesar $0,25 \%$ b/v. Komponen nitrogen merupakan salah satu macronutrients yang dibutuhkan oleh mikroba untuk menyusun protein, asam nukleat, dan koenzim (Shuler dan Kargi, 1992).

Pada konsentrasi ekstrak kulit pisang kepok $1000 \mathrm{~g} / \mathrm{L}$ air dengan penambahan $0,5 \% \mathrm{~b} / \mathrm{v}$ $\left(\mathrm{NH}_{4}\right)_{2} \mathrm{SO}_{4}$, kadar TPC mengalami penurunan namun masih lebih tinggi jika dibandingkan tanpa penambahan $\left(\mathrm{NH}_{4}\right)_{2} \mathrm{SO}_{4}$ (Gambar 1). Hal ini disebabkan metabolisme Rhizopus oryzae berkurang akibat tingginya kandungan nitrogen pada ekstrak kulit pisang yang menyebabkan dinding sel mengalami lisis, yang berakibat pembentukan TPC ikut menurun. Peristiwa lisisnya dinding sel Rhizopus oryzae dapat dilihat dari Gambar 4 yang menunjukkan penurunan dried weight setelah waktu fermentasi 72 jam.

TAC juga memberikan kecendrungan yang sama dengan TPC, dimana peningkatan konsentrasi $\left(\mathrm{NH}_{4}\right)_{2} \mathrm{SO}_{4}$ pada konsentrasi ekstrak kulit pisang kepok $500 \mathrm{~g} / \mathrm{L}$ air juga memberikan hasil TAC yang meningkat berturut-turut adalah 29,83; 35,84 dan $49,00 \%$. Hal ini tidak terjadi pada penambahan konsentrasi $\left(\mathrm{NH}_{4}\right)_{2} \mathrm{SO}_{4}$ dalam konsentrasi ekstrak kulit pisang kepok $1000 \mathrm{~g} / \mathrm{L}$ air dimana TAC tertinggi sebesar $88,37 \%$ diperoleh pada saat penambahan $\left(\mathrm{NH}_{4}\right)_{2} \mathrm{SO}_{4} 0,25 \% \mathrm{~b} / \mathrm{v}$.

\section{KESIMPULAN}

Rhizopus oryzae memproduksi senyawa fenolik tertinggi setelah waktu fermentasi 72 jam dengan TPC sebesar 582,07 mg GAE/L ekstrak dan TAC 88,37\% menggunakan konsentrasi ekstrak kulit pisang kepok $1000 \mathrm{~g}$ kulit pisang kepok/L air dengan penambahan $0,25 \% \mathrm{~b} / \mathrm{v}\left(\mathrm{NH}_{4}\right)_{2} \mathrm{SO}_{4}$.

\section{DAFTAR PUSTAKA}

Andayani, R., Maimunah, dan Lisawati, Y., (2008), Penentuan aktivitas antioksidan, kadar fenolat total, dan likopen pada buah tomat, Jurnal Sains dan Teknologi Farmasi, 13(1), pp.1-6.

Atun, S., Arianingrum, R., Handayani, S., Rudyansah, and Garson, M., (2007), Identification and antioxidant activity test of some compounds from mathanol extract peel of banana (Musa paradisiaca Linn.), Indo. J. Chem., 7(1), pp. 83-87.

Correia, R.T.P., McCue, P., Magalhaes, M.M.A., Macedo, G.R., and Shetty, K., (2004), Production of phenolic antioxidants by the solid-state bioconversion of pineapple waste mixed with soy flour using Rhizopus oligosporus, Process Biochemistry, 39, pp. 2167-2172.

Costa, A.M., Souza, C.G.M., Bracht, A., Kadowaki, M.K., Souza, A.C.S., Oliveira, R.F., and Peralta, R.M., (2013), Production of tannase and gallic acid by Aspergillus tamarii in submerged and solid state cultures, African Journal of Biochemistry Research, 7(10), pp.197-202.

Dey, T.B. and Kuhad, R.C., (2014), Enhanced production and extraction of phenolic compounds from wheat by solid-state fermentation with Rhizopus oryzae RCK2012, Biotechnology Reports, 4, pp. 120127.

Direktorat Jenderal Hortikultura, (2005), Angka Tetap Komoditas Hortikultura Tahun 2004, Jakarta, Direktorat Jenderal Hortikultura. 
Fresco, P., Borges, F., Diniz, C., and Marques, M.P., (2006), New insights on anticancer properties of dietary polyphenols, Medical Research Reviews, 26, pp. 747-766.

Halliwell, B., (1996), Oxidative stress, nutrition and health. Experimental strategies for optimization of nutritional antioxidant intake in humans, Free Rad. Res., 25, pp. 57-74.

Lee, J.M., (1992), Biochemical Engineering, Prentice Hall, New Jersey, pp.94-95.

Mar'atirrosyidah, R. dan Estiasih, T., (2015), Aktivitas Antioksidan Senyawa Bioaktif UmbiUmbian Lokal Inferior : Kajian Pustaka, Jurnal Pangan dan Agroindustri, 3(2), hal. 594-601.

Marinova, D., Ribarova, F., and Atanassova, M., (2005), Total phenolics and total flavonoids in bulgarian fruits and vegetables, Journal of the University of Chemical Technology and Metallurgy, 40(3), pp. 255-260.

Nagarajaiah, S.B. and Prakash, J., (2011), Chemical composition and antioxidant potential of peels from three varieties of banana, As. J. Food Ag-Ind., 4(01), pp. 31-46.

Nguyen, T.B.T., Ketsa, S., and Van Doorn, W.G., (2003). Relationship between browning and the activities of polyphenol oxidase and phenylalanine ammonia lyase in banana peel during low temperature storage, Postharvest Biology and Technology, 30(2), pp. 187-193.

Sandhya, C., Sumantrha, A., Szakacs, G., and Pandey, A., (2005), Comparative evaluation of neutral protease production by Aspergillus oryzae submerged and solid-state fermentation, Process Biochemistry, 40, pp. 2688-2694.

Schmidt, C.G., Gonçalves, L.M., Prietto, L., Hackbart, H.S., and Furlong, E.B., (2014), Antioxidant activity and enzyme inhibition of phenolic acids from fermented rice bran with fungus Rizhopus oryzae, Food Chemistry,146, pp. 371-377.

Shuler, M.L. and Kargi, F., (1992). Bioprocess Engineering : Basic Concepts, Prentice Hall, New Jersey, pp. 71-72

Someya, S., Yoshiki, Y., and Okubo, K., (2002). Antioxidant compounds from banana (Musa Cavendish), Food Chemistry, 79, pp. 351-354.

Sudarmadji, S., Haryono, B., dan Suhardi, (2007). Prosedur Analisa Untuk Bahan Makanan dan Pertanian, Yogyakarta, Liberty.

Tjitradjaja, G., Yangga, K., Retnoningtyas, E.S., dan Antaresti, (2011), Biosintesa senyawa antioksidan pada fermentasi substrat cair kulit pisang dengan bantuan Aspergillus niger, Jurnal Saintek, Volume 8, Nomor 2, hal. 52-55.

Toma, M., Vinatoru, M., and Mason, T.J., (2001), Investigation of the effects of ultrasound on vegetal tissues during solvent extraction, Ultrasonic Sonochemistry, 8(2), pp. 137-142.

Zielinski, H. and Kozlowska, H., (2000), Antioxidant activity and total phenolics in selected cereal grains and their different morphological fractions, Journal of Agricultural and Food Chemistry, 48, pp. 2008-2016. 